\title{
Selective Oxidation of Ethylbenzene over Transition Metal Organic Framework Cu-BTC
}

\author{
Mei Mei Peng, Hyun Tae Jang and Muthiahpillai Palanichamy* \\ Chemical Engineering Department, Hanseo University, \\ Seosan, 356-706, South Korea \\ *palani_annachem@yahoo.com
}

\begin{abstract}
In this work, $C u_{3}(B T C)_{2}(C u-B T C)$ metal organic framework $(M O F)$, prepared by 3 different synthetic routes, was employed to the oxidation reaction of ethylbenzene (EB) to synthesize the pharmaceutical intermediate acetophenone (AP). The reaction was carried out in liquid phase using oxygen molecule as oxidizing agent. In the reaction process, no any other solvent was used. To optimize the reaction conditions, temperature, reaction time, catalyst load weight and $\mathrm{O}_{2}$ gas flow were investigated. The products were analyzed by gas chromatography $(G C)$. The results obtained from GC analysis showed $C u-B T C$ has a high selectivity toward to AP (around 95\%). The conversion of EB was $44.92 \%$ when the reaction was carried out at $150{ }^{\circ} \mathrm{C}$ for $24 \mathrm{~h}$ with a catalyst load weight $0.1 \mathrm{~g}$ and $\mathrm{O}_{2}$ flow $5.5 \mathrm{ml} / \mathrm{min}$.
\end{abstract}

Keywords: Acetophenone, oxidation reaction, ethylbenzene, $M O F s, C u-B T C$

\section{Introduction}

Acetophenone (AP) is a well know intermediate in chemical industries. It has found many applications in organic industries. It forms light-resistant resins while reacting with formaldehyde to yield that resin is used as an additives in nitrocellulose [1]. Apart from the above it is also used as a photoinitiator, in pharmaceutical as an intermediate for some drugs, perfumery and pesticide industries. Hoechst-Celanese and Boots have developed p-isobutyl phenyl ethyl alcohol an intermediate synthesized by the hydrogenation of p-isobutyl acetophenone by new catalytic hydrogenation route for Ibuprofen, a non-steroidal antiinflammatory drug [2] and a derivative of AP called 4-methylacetophenone is useful in the synthesis of p-chlorocelecoxib a potential anti-inflammatory drug. AP derivative named 1phenylethanol is used for the production of aromatic ester fragrance [3]. Hock process is used industrially for the production of AP by cleavage of cumene hydroperoxide over a cupric catalyst [4]. AP can also be produced from methyl phenyl carbinol [5, 6] by oxidation.

Friedel-Crafts acylation of aromatic hyderocarbon using acetyl chloride with stoichiometric quantities of homogeneous Lewis acids such as $\mathrm{AlCl}_{3}, \mathrm{FeCl}_{3}$ but this reaction will emit large amounts of highly toxic and corrosive gases [7]. Another important and feasible way to produce AP is by the oxidation of EB over homogeneous transition metal (viz. $\mathrm{Co}, \mathrm{Mn}, \mathrm{Cu}$, or $\mathrm{Fe}$ ) compounds as catalysts in presence of oxygen or air $[8,9]$. But the use of homogeneous metal compound catalyst endures several drawbacks: the reaction conditions in this process are often harsh, the product selectivity is poor, and the catalyst gives rise to many problems such as handling, catalyst recovery and recycling. Considering the economic and environmental points of view, it is therefore of great practical interest to develop a more 
efficient, easily separable, reusable, and environmental-friendly catalyst for the production of AP [10].

Recently metal complex were identified as another catalyst system for alkyl aromatics, for instance, phosphorus-tungsten metal complex and phosphorus-molybdenum metal complex have been developed for the oxidation of alkyl aromatics. With these traditional catalytic systems, the main problem is the generation of large amount of waste during the reaction process, which makes the traditional processes environmental and economic unacceptable.

Recent years, solid heterogeneous catalyst has been widely explored by chemical researchers because they are versatile in reactivity, environmentally harmless and can assist for green synthesis, non-corrosive and easy to recover while compared with homogeneous catalyst [11]. Mesoporous materials such as zeolites and silica are important catalysts in organic synthesis field because they are versatile in structure and their catalytic properties can be tailored via a large number of modification procedures. Transition metal loaded Zeolite and mesoporous silicas, for example M-MCM-41(M=Ti, V, Cr) [12] and $\mathrm{Ag} / \mathrm{CeO}_{2}-\mathrm{SiO}_{2}$ [13], have been studied for the oxidation reaction of alkyl aromatics. However, because of the serious pore size constraints, the accessibility of active metal sites is highly limited for larger aromatic substrates in these materials.

Metal Organic Frameworks (MOFs) is a new class of microporous material with many potential advantages such as well-defined structures, controlled pore size, high thermal and chemical stability, high surface area, low density, desired chemical functional groups and so on [14-18]. These attractive properties allow MOFs possible apply in gas storage, gas/vapor separation, size-, shape-, and enantio-selective catalysis [19-21]. As a catalyst, MOFs have been proved to own a great advantage that the active sites almost same due to their highly crystalline nature. In addition, the pores of MOFs can be tailored in a systematic way allowing optimization for specific catalytic applications [22]. These properties make MOFs a premising material for application in catalyst. However, up to now the studies on alkyl aromatic oxidation reactions under the catalytic condition of MOFs still not enough, only a few examples have been reported [23]. Further the earlier reports also support the usefulness of $\mathrm{Cu}$ and its oxides for the oxidation alkyl aromatics. These evidences encourage us to select the $\mathrm{Cu}-\mathrm{BTC}$ for the oxidation of ethyl benzene to produce AP, among the MOF studied $\mathrm{Cu}$ BTC have more number of free metal sites on its surface to carry out the catalytic reactions. Here in our paper we studied the catalyst performance of $\mathrm{Cu}$-BTC in the aerobic oxidation reaction of EB using oxygen as source for singlet oxygen production.

\section{Experimental}

\subsection{Materials}

Copper (II) nitrate trihydrate [Cu $\left(\mathrm{NO}_{3}\right)_{2} \cdot 3 \mathrm{H}_{2} \mathrm{O}$, Daejung chemicals \& metals, 99\%], benzene-1, 3, 5-tricarboxylic acid (BTC, Sigma Aldrich, $\mathrm{C}_{9} \mathrm{H}_{6} \mathrm{O}_{6}, 95 \%$ ). Ethyl benzene $\left[\mathrm{C}_{6} \mathrm{H}_{5} \mathrm{C}_{2} \mathrm{H}_{5}\right.$, Junsei chemical, 98\%], The solvents, ethyl alcohol anhydrous $\left(\mathrm{C}_{2} \mathrm{H}_{5} \mathrm{OH}\right.$, Daejung chemicals \& metals 99.9\%), N, N-dimethylformamide [DMF, HCON $\left(\mathrm{CH}_{3}\right)_{2}$, Daejung chemicals \& metals 99.5\%], chloroform $\left[\mathrm{CHCl}_{3}\right.$, Daejung chemicals \& metals 99.5\%], deionized (DI) water were used in the synthesis.

\subsection{Synthesis of catalyst}

$\mathrm{Cu}\left(\mathrm{NO}_{3}\right)_{2} \bullet 3 \mathrm{H}_{2} \mathrm{O}(1.75 \mathrm{~g}, 7.2 \mathrm{mmol})$ was dissolved into $24 \mathrm{ml}$ DI water, and BTC (0.84 g, $4 \mathrm{mmol}$ ) was dissolved into $24 \mathrm{ml}$ ethanol under stirring at room temperature. Then the copper solution was added to the BTC solution and stirred for $1 \mathrm{~h}$. The mixture was 
transferred to a Teflon lined stainless steel autoclave and kept at $120^{\circ} \mathrm{C}$ for $12 \mathrm{~h}$. The reaction vessel was cooled to ambient temperature, centrifuged and the solid product was vacuum dried at room temperature to yield sample, $\mathrm{Cu}$-BTC-(1) [24].

$\mathrm{Cu}-\mathrm{BTC}-(2)$ was synthesized following the procedure reported by Xiang et al., [25]. BTC $(2.5 \mathrm{~g}, 12 \mathrm{mmol})$ and $\mathrm{Cu}\left(\mathrm{NO}_{3}\right)_{2} \cdot 3 \mathrm{H}_{2} \mathrm{O}(5 \mathrm{~g}, 20.7 \mathrm{mmol})$ were added in a $250 \mathrm{ml}$ bottle in 125 $\mathrm{ml}$ solvent consisting of DMF, ethanol, and DI water with a ratio of 1:1:1, after sonication for $15 \mathrm{~min}$, the bottle was placed in an oven at $85{ }^{\circ} \mathrm{C}$ for $20 \mathrm{~h}$. The product was isolated by filtration and rinsed with $3 \times 10 \mathrm{ml} \mathrm{DMF}$, and then immersed in $\mathrm{CHCl}_{3}$ for 3 days, during which the activation solvent was decanted and replaced freshly thrice. The product was dried at $200{ }^{\circ} \mathrm{C}$ in vacuum to yield $\mathrm{Cu}-\mathrm{BTC}-2$ sample.

$\mathrm{Cu}-\mathrm{BTC}-(3)$ was synthesized following the procedure reported by Xiang et al., [25]. BTC $(2.5 \mathrm{~g}, 12 \mathrm{mmol})$ and $\mathrm{Cu}\left(\mathrm{NO}_{3}\right)_{2} \cdot 3 \mathrm{H}_{2} \mathrm{O}(5 \mathrm{~g}, 20.7 \mathrm{mmol})$ were added in a $500 \mathrm{ml}$ beaker in 125 $\mathrm{ml}$ solvent containing DMF, ethanol, and DI water with a ratio of 1:1:1. After sonication for $15 \mathrm{~min}$, the beaker was then placed inside household microwave oven (Goldstar, $\mathrm{MH}-700 \mathrm{H}$ ) and heated at $700 \mathrm{~W}$ for $4 \mathrm{~min}$, during which the beaker was put out from microwave oven for a little while with slight stir every $30 \mathrm{~s}$ to avoid explosion. A blue suspension was obtained. The product was isolated and then rinsed with 3x10 ml DMF. After exchanging with $\mathrm{CHCl}_{3}$ for three days, the product was dried at $200{ }^{\circ} \mathrm{C}$ in vacuum to yield $\mathrm{Cu}-\mathrm{BTC}-(3)$.

\subsection{Catalyst characterization}

Powder X-ray diffraction (XRD) patterns were recorded using a Rigaku D/Max $2200+$ Ultima diffractometer with $\mathrm{Cu}-\mathrm{K} \alpha$ radiation $(\lambda=0.154 \mathrm{~nm})$. The diffraction data were recorded in the $2 \theta$ range $5-50^{\circ}$ with a step of $0.02 \%$. Thermogravimetric analysis (TGA) was performed on Scinco TGA N-1000 thermo gravimetric (TG) analyzer, the sample was heated from room temperature to $800{ }^{\circ} \mathrm{C}$ under $\mathrm{N}_{2}$ at a temperature ramp of $10{ }^{\circ} \mathrm{C} / \mathrm{min}$. The nitrogen adsorption-desorption isotherms were measured at $77 \mathrm{~K}$ on a Belsorp mini II volumetric adsorption analyzer. Prior to each adsorption measurement the samples were evacuated at $200{ }^{\circ} \mathrm{C}$ under vacuum $(\mathrm{p}<10-5 \mathrm{mbar})$ for $6 \mathrm{~h}$ in the degassing port. The surface area $\left(\mathrm{S}_{\mathrm{BET}}\right)$ was determined from the linear part of the Brunauer-Emmett-Teller (BET) equation, and the pore volume was calculated using a BET plot based on the amount of nitrogen gas adsorbed at the last adsorption point $\left(\mathrm{p} / \mathrm{p}_{0}=0.99\right)$ and the pore size distribution using the BarrettJoyner-Halenda (BJH) method. SEM images were captured on JEOL JSM 5600 scanning electron microscope.

\subsection{Catalyst activity (oxidation of ethyl benzene)}

The catalyst performance of $\mathrm{Cu}$-BTC on the oxidation of EB was studied in solvent-free condition. The reaction procedure was according to the previous work [26] with a little modification. In a typical run, $10 \mathrm{ml} \mathrm{EB}$ and $0.1 \mathrm{~g} \mathrm{Cu}$-BTC were taken in a $50 \mathrm{ml}$ round bottom flask which has a water-cooled condenser and $\mathrm{O}_{2}$ gas inlet. The mixture was heated at constant temperature of $150{ }^{\circ} \mathrm{C}$ with continuous $\mathrm{O}_{2}$ gas flow $5.5 \mathrm{ml} / \mathrm{min}$ with stirring for $6 \mathrm{~h}$. Then the reaction mixture was cooled to room temperature and the catalyst was separated from the reaction mixture by filtration. The catalyst was dried at $100{ }^{\circ} \mathrm{C}$ for subsequent using. In order to optimize the reaction conditions, the temperature $\left(120,130,140,150,160{ }^{\circ} \mathrm{C}\right)$, time $(6,15,20,24,48 \mathrm{~h})$, catalyst weight $(0.03,0.05,0.07,0.1,0.15 \mathrm{~g})$ and $\mathrm{O}_{2}$ flow $(3.5,5.5$, $7.5,10 \mathrm{ml} / \mathrm{min}$ ) were investigated. The products were analyzed by GC (Agilent, HP-5 column $50 \mathrm{~m} \times 320 \mu \mathrm{m} \times 0.52 \mu \mathrm{m}$ and FID detector) and GC-MS (Bruker, VF-5ms column $30 \mathrm{~m} \times$ $0.53 \mathrm{~mm} \times 1.5 \mu \mathrm{m})$ wherever required. 


\section{Results and discussion}

\subsection{Characteristics of catalyst}

Figure 1 A shows the XRD patterns of prepared Cu-BTC samples. The XRD patterns of the $\mathrm{Cu}-\mathrm{BTC}$ obtained by the three methods were almost similar with each other, and coincided closely with the $\mathrm{Cu}$-BTC reported in literature [24]. It indicated that the three samples synthesized by different methods have the same crystal structure.

The SEM images of the synthesized samples are presented in Figure 1 B They showed octahedral morphology [27]. The crystals of Cu-BTC-(1), Cu-BTC-(2) were almost similar while $\mathrm{Cu}-\mathrm{BTC}-(3)$ was smaller in size which was in accordance with the previous report [25]. Smaller dimensions of the latter were due to homogeneous effect. More seeds were formed in a short time, leading to a little chance for the seeds to grow up while using microwave.
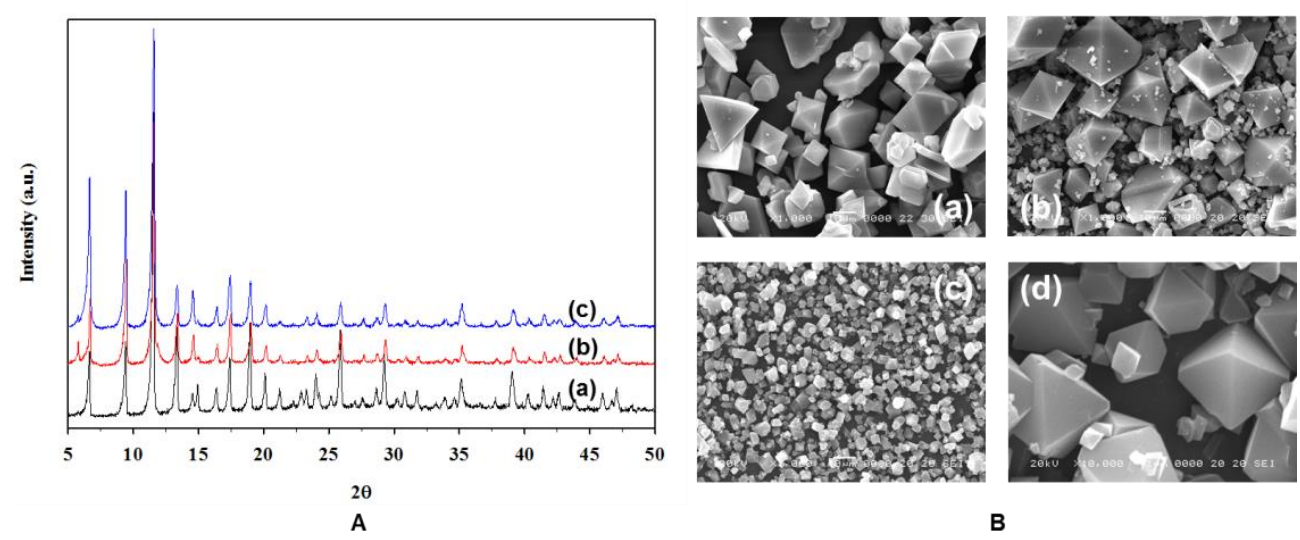

Figure 1. A. XRD patterns of Cu-BTC prepared with different methods. (a) CuBTC-(1), (b) Cu-BTC-(2) and (c) Cu-BTC-(3)

\section{B. SEM images of Cu-BTC prepared with different methods. (a) Cu- BTC-(1), (b) Cu-BTC-(2), (c) Cu-BTC-(3) and (d) Cu-BTC-(3) at 10,000 magnification}

The nitrogen adsorption-desorption isotherms of $\mathrm{Cu}$-BTC samples are shown in Figure 2. All of them displayed Type I isotherm, a signature characteristic of microporous materials. The surface area and pore volume $\mathrm{Cu}-\mathrm{BTC}-(3)$ was found to be $1721 \mathrm{~m}^{2} \mathrm{~g}^{-1}$ and $0.7424 \mathrm{~cm}^{3} \mathrm{~g}^{-1}$ respectively. The later was the higher than $\mathrm{Cu}-\mathrm{BTC}-(1)$ and $\mathrm{Cu}-\mathrm{BTC}-(2)$ (Table 1). The results are in line with the previous reports [25]. The surface area and pore volume of $\mathrm{Cu}-\mathrm{BTC}-(3)$ was almost nearer to value reported by Millward and Yaghi [28].

The thermograms of the synthesized samples are presented in Figure 3. Prior to analysis, the samples were preheated in a vacuum oven remove the physisorbed water and gases. Initial weight loss below $150{ }^{\circ} \mathrm{C}$ is attributed to desorption of the coordinated water. A weight loss of about 5.2 and $3.4 \%$ was observed for Cu-BTC-(1) and (2) while a loss of about $7.6 \%$ was noted for $\mathrm{Cu}$-BTC-(3), hence the latter retains more amount of water. The second weight loss around above $300{ }^{\circ} \mathrm{C}$ was due to the decomposition of the organic network. All of the $\mathrm{Cu}$-BTC samples were found to be stable upto $300{ }^{\circ} \mathrm{C}$. 


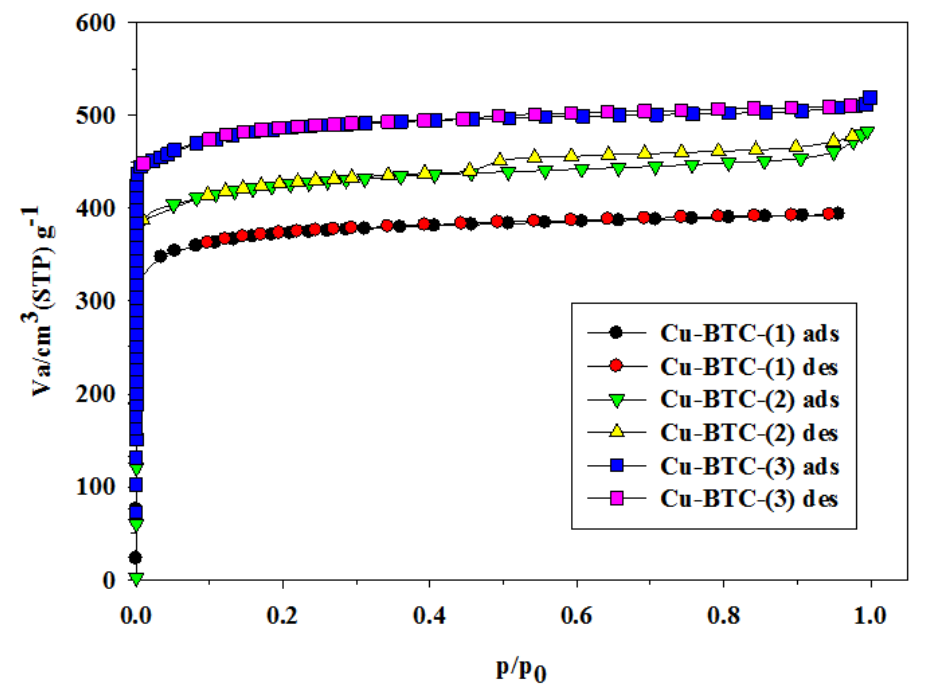

Figure 2. $\mathrm{N}_{2}$ adsorption isotherms of Cu-BTC prepared with different methods

Table 1. Porosity properties of Cu-BTC prepared with different methods

\begin{tabular}{cccc}
\hline Sample & $\mathrm{S}_{\mathrm{BET}}\left(\mathrm{m}^{2} \mathrm{~g}^{-1}\right)$ & $\begin{array}{c}\text { Total pore volume } \\
\left(\mathrm{cm}^{3} \mathrm{~g}^{-1}\right)\end{array}$ & $\begin{array}{c}\text { Average pore } \\
\text { diameter } \\
(\mathrm{nm})\end{array}$ \\
\hline Cu-BTC-(1) & 1465.0 & 0.6079 & 1.6600 \\
$\mathrm{Cu}-$ BTC-(2) & 1656.8 & 0.7130 & 1.6571 \\
$\mathrm{Cu}-$ BTC-(3) & 1721.0 & 0.7424 & 1.7924 \\
\hline
\end{tabular}

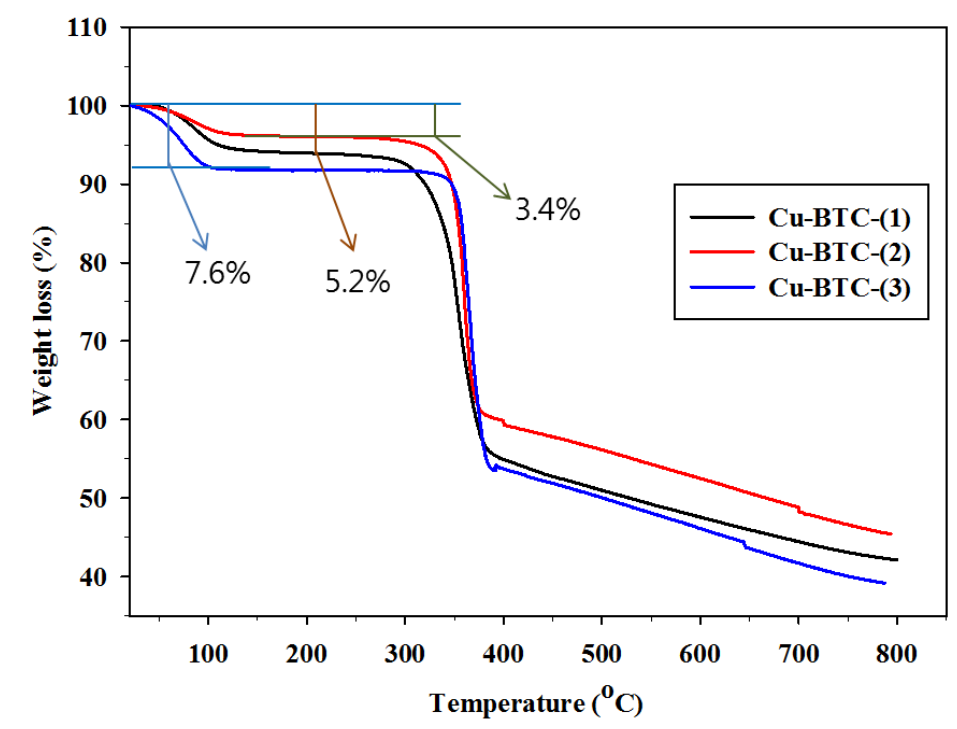

Figure 3. TGA curves of Cu-BTC prepared with different methods 


\subsection{Catalytic activity}

3.2.1. Effect of temperature: The synthesized $\mathrm{Cu}$-BTC samples were studied for the oxidation of EB. In order to investigate the effect of temperature, the reaction was studied at $120,130,140,150$ and $160{ }^{\circ} \mathrm{C}$. The reaction was carried out for $6 \mathrm{~h}$ with $\mathrm{O}_{2}$ gas flow of 5.5 $\mathrm{ml} / \mathrm{min}$. The GC analysis results were shown in Table 2. The oxidation of EB over $\mathrm{Cu}-\mathrm{BTC}$ catalyst results in acetophenone (AP), benzaldehyde (BZ) and benzoic acid (BA). For all synthesized Cu-BTC samples the selectivity of AP was similar with each other (values were around $95 \%$ ), which illustrated that $\mathrm{Cu}-\mathrm{BTC}$ material can effectively improve the product selectivity of AP. Among the three samples, Cu-BTC-(3) exhibited a little higher conversion of EB than $\mathrm{Cu}-\mathrm{BTC}-(1)$ and (2), this because Cu-BTC-(3) has a higher surface area than other two samples, which could absorb more EB to react with $\mathrm{O}_{2}$, as heterogeneous catalysis reaction the reactants diffuse to the catalyst surface and adsorb onto it, via the formation of chemical bonds, after reaction, the products desorb from the surface and diffuse away, so for solid heterogeneous catalysts, the surface area of the catalyst is important.

As show in Table 2, the conversion of EB increased with increasing temperature up to $150{ }^{\circ} \mathrm{C}$ and then decrease. The same phenomenon was also happen to the selectivity of AP. The selectivity of AP was $96.12 \%$ at $140{ }^{\circ} \mathrm{C}$, a little higher than that at $150{ }^{\circ} \mathrm{C}(95.77 \%)$, however, EB conversion at $140{ }^{\circ} \mathrm{C}(21.75 \%)$ was much lower than that of $150{ }^{\circ} \mathrm{C}$ (28.26\%). Therefore consider of both EB conversion and AP selectivity, $150{ }^{\circ} \mathrm{C}$ is the suitable reaction temperature.

Table 2. EB oxidation reaction over $\mathrm{Cu}-\mathrm{BTC}$ at different temperatures

\begin{tabular}{|c|c|c|c|c|c|c|}
\hline \multirow[t]{2}{*}{ Catalyst } & \multirow{2}{*}{$\begin{array}{c}\text { Temperature } \\
\left({ }^{\circ} \mathrm{C}\right)\end{array}$} & \multirow{2}{*}{$\begin{array}{c}\text { EB Conversion } \\
(\%)\end{array}$} & \multicolumn{4}{|c|}{ Product Selectivity (\%) } \\
\hline & & & $\mathrm{AP}$ & $\mathrm{BZ}$ & BA & Others \\
\hline / & 150 & 5.01 & 57.47 & 1.94 & 35.84 & 4.75 \\
\hline $\mathrm{Cu}-\mathrm{BTC}-(1)$ & 150 & 19.59 & 92.37 & 3.23 & 0.34 & 4.06 \\
\hline $\mathrm{Cu}-\mathrm{BTC}-(2)$ & 150 & 22.27 & 95.36 & 1.68 & 1.81 & 1.15 \\
\hline $\mathrm{Cu}-\mathrm{BTC}-(3)$ & 150 & 28.26 & 95.77 & 1.84 & 1.18 & 1.21 \\
\hline \multirow[t]{5}{*}{ Cu-BTC-(3) } & 120 & 10.61 & 82.35 & 2.01 & 13.88 & 1.76 \\
\hline & 130 & 17.48 & 93.64 & 3.92 & 0.34 & 2.10 \\
\hline & 140 & 21.75 & 96.12 & 1.62 & 1.36 & 0.90 \\
\hline & 150 & 28.26 & 95.77 & 1.84 & 1.18 & 1.21 \\
\hline & 160 & 19.08 & 95.06 & 2.55 & / & 2.39 \\
\hline
\end{tabular}

(Reaction time: $6 \mathrm{~h}$, catalyst weight: $0.10 \mathrm{~g}, \mathrm{O}_{2}$ flow rate: $5.5 \mathrm{ml} / \mathrm{min}$.)

3.2.2. Effect of time: EB oxidation was carried out at $150{ }^{\circ} \mathrm{C}$ for 5 different reaction times $(6$, $15,20,24,48 \mathrm{~h}$ ) over Cu-BTC-(3), the catalyst weight was $0.1 \mathrm{~g}$ and $\mathrm{O}_{2}$ flow was $5.5 \mathrm{ml} / \mathrm{min}$. The results were displayed in Figure 4. EB conversion increased with increasing in reaction time, while the selectivity of AP was observed a slightly decrease with increasing reaction time. Here $49.92 \%$ of EB conversion and $92.53 \%$ of AP selectivity were obtained for a $24 \mathrm{~h}$ reaction time. Hamidipour et al., [23] have reported EB oxidation using a $\mathrm{Co}$ (II) metalorganic framework Co-MOF, they got a 100\% selectivity of AP during $24 \mathrm{~h}$ reaction, however the conversion of EB was only $23 \%$, much lower than that in this work. Moreover, in the reaction process they used acetonitrile, a toxic and harmful substance, as solvent; in this work, the oxidation was carried out in solvent-free condition 


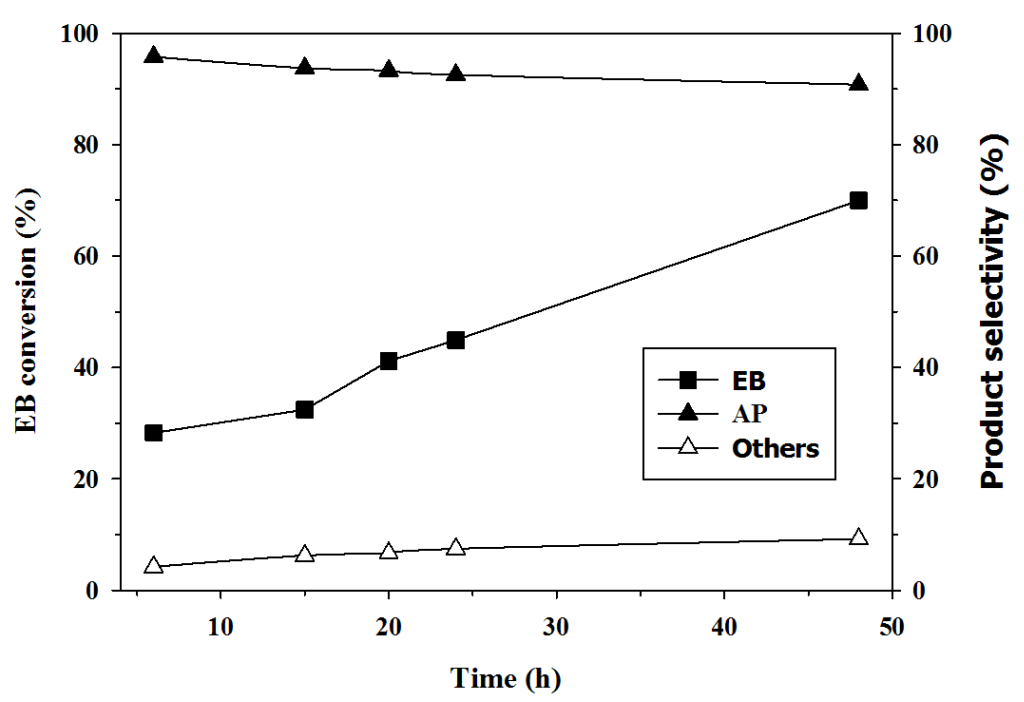

Figure 4. Time effect on EB conversion and AP selectivity over Cu-BTC-(3).

3.2.3. Effect of $\mathrm{O}_{2}$ flow rate: The effect of $\mathrm{O}_{2}$ gas flow rate on $\mathrm{EB}$ conversion and $A P$ selectivity was studied at $150{ }^{\circ} \mathrm{C}$ for $24 \mathrm{~h}$ with different $\mathrm{O}_{2}$ flow rate $(3.5,5.5,7.5,10 \mathrm{ml} / \mathrm{min})$ and the results were shown in Figure 5. EB conversion increased with increasing in $\mathrm{O}_{2}$ gas flow rate and then decreased, at the value of $5.5 \mathrm{ml} / \mathrm{min}$, a maximum EB conversion $(49.92 \%)$ was exhibited. When flow of $\mathrm{O}_{2}$ increase it cause vaporization of $\mathrm{EB}$ hence a certain quantity of EB could not have contact with the catalyst, consequently the concentration of EB around catalyst was decreased, which is the reason in the decrease in EB conversion at high $\mathrm{O}_{2}$ gas flow rate. AP selectivity did not show any obvious change in different $\mathrm{O}_{2}$ gas flow rate, a high and stable selectivity was displayed throughout.

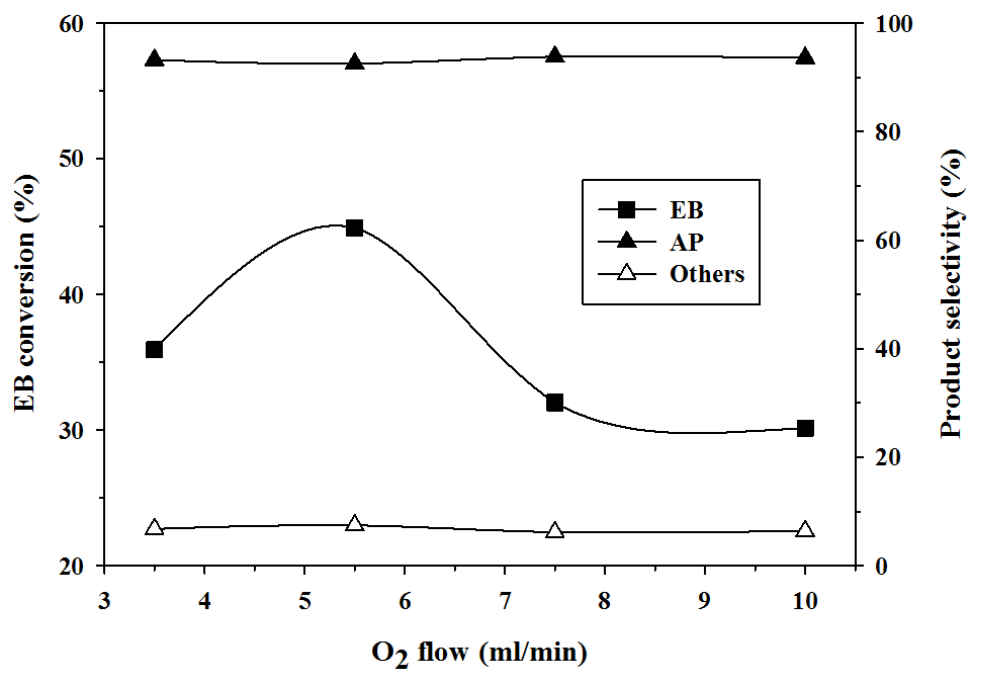

Figure $5 . \mathrm{O}_{2}$ flow rate effect on EB conversion and AP selectivity over Cu-BTC-(3) 
3.2.4. Effect of catalyst weight: In order to study the catalyst weight effect on $E B$ conversion and AP selectivity, the reaction was carried out at $150{ }^{\circ} \mathrm{C}$ for $24 \mathrm{~h}$ with $\mathrm{O}_{2}$ flow rate 5.5 $\mathrm{ml} / \mathrm{min}$, the catalyst weight was from 0.03 to $0.15 \mathrm{~g}$. The results were displayed in Figure 6. The conversion of EB increased with increasing catalyst weight from 0.03 to $0.1 \mathrm{~g}$, while at the catalyst weight of $0.15 \mathrm{~g}$ it decreased. The selectivity of AP was almost same when the catalyst weight was changed from 0.03 to $0.15 \mathrm{~g}$, which indicated that $\mathrm{Cu}-\mathrm{BTC}$ kept high stable selectivity toward to AP.

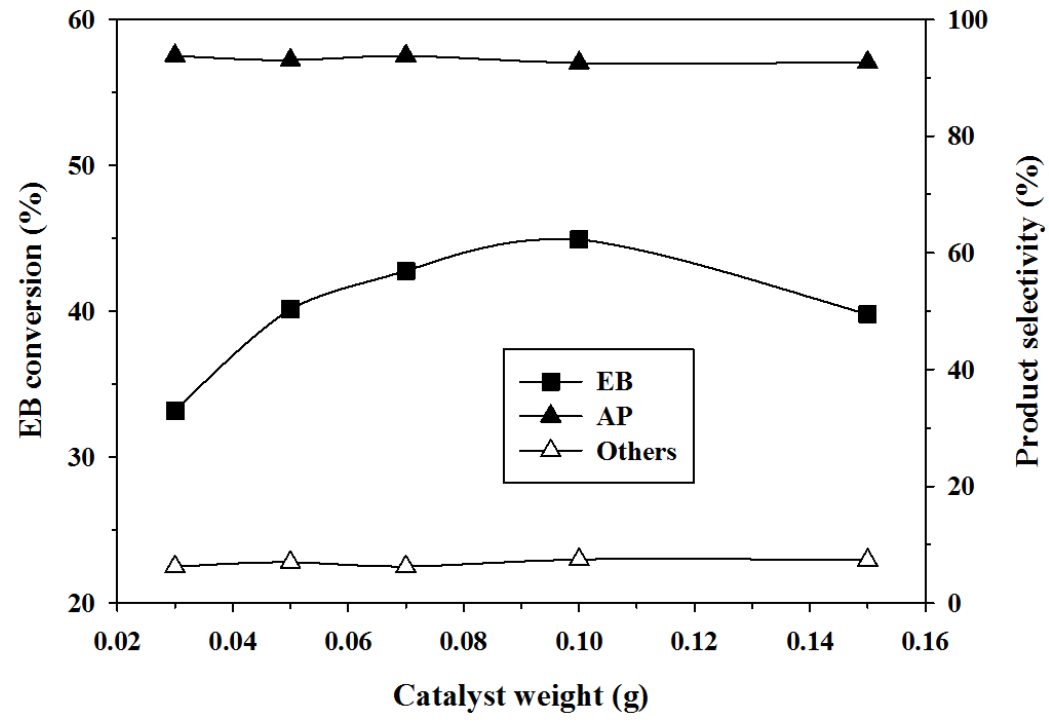

Figure 6. Catalyst weight effect on EB conversion and AP selectivity over CuBTC-(3)

3.2.5. Recycling experiment: The stability of the catalyst was also studied to test the lifetime of the catalyst. After reaction, the catalyst was separated from the reaction mixture, washed with ethanol and dried at $100{ }^{\circ} \mathrm{C}$ overnight. EB oxidation was carried out under the same reaction conditions using the regenerated catalysts. The recycling experiment was repeated four times and the results were shown in Table 3. EB conversion decreased slowly in each run, however, no sharp change was observed in the selectivity of AP, which confirmed that $\mathrm{Cu}$ BTC is a high AP selective and stable heterogeneous catalyst to EB oxidation.

Table 3. Recyclability of Cu-BTC-(3).

\begin{tabular}{ccccccc}
\hline Catalyst & Run & $\begin{array}{c}\text { EB Conversion } \\
(\%)\end{array}$ & AP & BZ & BA & Others \\
\hline Cu-BTC-(3) & 1 & 44.92 & 92.53 & 1.07 & 3.15 & 3.25 \\
& 2 & 40.24 & 92.65 & 1.45 & 3.12 & 2.78 \\
& 3 & 35.49 & 92.87 & 1.37 & 3.54 & 2.22 \\
& 4 & 33.05 & 92.86 & 1.38 & 3.18 & 2.57 \\
& 5 & 32.26 & 93.53 & 1.27 & 3.06 & 2.13 \\
\hline
\end{tabular}

(Temperature: $100^{\circ} \mathrm{C}$, reaction time: $24 \mathrm{~h}$, catalyst weight: $0.10 \mathrm{~g}, \mathrm{O}_{2}$ flow rate: $5.5 \mathrm{ml} / \mathrm{min}$.) 


\section{Conclusions}

Copper based metal organic framework Cu-BTC was successfully employed for the selective oxidation of EB under solvent-free condition using molecular oxygen as oxidant. In order to optimize reaction conditions, in the reaction process, temperature, time, $\mathrm{O}_{2}$ gas flow rate and catalyst weight effect were investigated. The results analyzed by $\mathrm{GC}$ showed $\mathrm{Cu}$ BTC exhibited high AP selectivity. From the study conducted it was concluded that the temperature $150{ }^{\circ} \mathrm{C}$ is optimum for carry out the reactions, the maximum time needed for reaction is $24 \mathrm{~h}$ with $0.1 \mathrm{~g}$ catalyst and $5.5 \mathrm{ml} / \mathrm{min}_{2}$ gas flow rate required for the successful reaction, $44.92 \% \mathrm{~EB}$ conversion, $92.53 \% \mathrm{AP}$ selectivity were obtained. In addition, stability of $\mathrm{Cu}-\mathrm{BTC}$ catalyst was studied by recycling experiments using recovered catalyst. The results showed $\mathrm{Cu}-\mathrm{BTC}$ was effective and reusable catalyst for selective oxidation of EB to get product AP.

\section{Acknowledgements}

This work was supported by the 2012 Research Grant of Hanseo University.

\section{References}

[1] J. I. Kroschwitz and M. Howe-Granct, (Eds.), Kirk-Othmer, Encyclopedia of Chem. Techn., 4th Ed. New York, (1995), pp. 1011

[2] J. S. Nicholson and S. S. Adams, Phenyl propionic acids. U.S. Patent 3, 385, 886, (1968) May 28.

[3] K. Baver and D. Garbe, "Common Fragrance and Flavor Material", VCH Publishers, Weinheim, (1985), pp. 73.

[4] P. E. Bast and G. Lartigem, "Preparation of acetophenone", U.S. Patent 3, 968, 162, (1976) July 6

[5] H. F. Keag, H. S. McCullough and H. J. Sanders, Ind. Eng. Chem., vol. 2, no. 45, (1953). Doi: http://dx.doi.org/10.1021/ie50517a017.

[6] V. Hansel, "Production of acetophenone", U.S. Patent 2, 797, 245, (1957) June 25.

[7] G. A. Olah, Friedel-Crafts and related reactions, Wiley-Interscience, New York (1963)

[8] B. B. Wentzel, M. P. J. Donners, P. L. Alsters, M. C. Feiters and R. J. M. Nolte, Tetrahedron., vol. 7797, no. 56, (2000), Doi: http://dx.doi.org/10.1016/S0040-4020(00)00679-7.

[9] C. T. Kresge, M. E. Leonowicz, W. J. Roth, J. C. Vartulli and J. S. Beck, Nature, vol. 710, no. 359, (1992), Doi: http://dx.doi.org/10.1038/359710a0.

[10] K. M. Parida and S. S. Dash, J. Mol Catal A. 54, 306 (2009). Doi: http://dx.doi.org/10.1016/j.molcata.2009.02.022

[11] I. Fechete, Y. Wang and J. C. Védrine, Catalysis Today, vol. 2, no. 189, (2012), Doi: http://dx.doi.org/10.1016/j.cattod.2012.04.003.

[12] R. K. Jha, S. Shylesh, S. S. Bhoware and A. P. Singh, Micropor. Mesopor. Mater., vol. 154, no. 95, (2006), Doi: http://dx.doi.org/10.1016/j.micromeso.2006.04.018.

[13] M. J. Beier, B. Schimmoeller, T. W. Hansen, J. E. T. Andersen, S. E. Pratsinis and J. D. Grunwaldt, J. Molecular Catalysis A: Chemical., vol. 40, no. 331, (2010), Doi: http://dx.doi.org/10.1016/j.molcata.2010.08.001.

[14] R. Banerjee, H. Furukawa, D. Britt, C. Knobler, M. O’Keeffe and O. M. Yaghi, J. Am. Chem. Soc., vol. 3875, no. 131, (2009), Doi: http://dx.doi.org/10.1021/ja809459e.

[15] G. Ferey, Chem. Soc. Rev., vol. 191, no. 37, (2008), Doi: http://dx.doi.org/10.1039/B618320B.

[16] O. M. Yaghi, M. O'Keeffe, N. W. Ockwig, H. K. Chae, M. Eddaoudi and J. Kim, Nature, vol. 705, no. 423, (2003), Doi: http://dx.doi.org/10.1038/nature01650.

[17] J. L. C. Rowsell and O. M. Yaghi, Micropor. Mesopor. Mater., vol. 3, no. 73, (2004), Doi: http://dx.doi.org/10.1016/j.micromeso.2004.03.034.

[18] R. Q. Snurr, J. T. Hupp and S. T. Nguyen, J. AIChE, vol. 1090, no. 50, (2004), Doi: http://dx.doi.org/10.1002/aic.10101.

[19] C. Serre, F. Millange, S. Surble and G. Ferey, Angew, Chem. Int. Ed. Engl., vol. 6285, no. 43, (2004), Doi: http://dx.doi.org/10.1002/anie.200454250. 
[20] P. Horcajada, C. Serre, G. Maurin, N. A. Ramsahye, F. Balas, M. Vallet-Regi, M. Sebban, F. Taulelle and G. Ferey, J. Am. Chem. Soc., vol. 6774, no. 130, (2008), Doi: http://dx.doi.org/10.1021/ja710973k.

[21] Y. K. Park, S. B. Choi, H. Kim, K. Kim, B. H. Won, K. Choi, J. S. Choi, W. S. Ahn, N. Won, S. Kim, D. H. Jung, S. H. Choi, G. H. Kim, S. S. Cha, Y. H. Jhon, J. K. Yang and J. Kim, Angew. Chem. Int. Ed. Engl., vol. 8230, no. 46, (2007), Doi: http://dx.doi.org/10.1002/anie.200702324.

[22] R. J. Kuppler, D. J. Timmons, Q. R. Fang, J. R. Li, T. A. Makal, M. D. Young, D. Q. Yuan, D. Zhao, W. J. Zhuang and H. C. Zhou, Coordination Chemistry Reviews, vol. 3042, no. 253, (2009), Doi: http://dx.doi.org/10.1016/j.ccr.2009.05.019.

[23] L. Hamidipour and F. Farzaneh, Reac Kinet Mech Cat., Doi: http://dx.doi.org/10.1007/s11144-0120533-2.

[24] K. Schlichte, T. Kratzke and S. Kaskel, Micropor. Mesopor. Mater., vol. 81, no. 73, (2004), Doi: http://dx.doi.org/10.1016/j.micromeso.2003.12.027.

[25] Z. H. Xiang, D. P. Cao, X. H. Shao, W. C. Wang, J. W. Zhang and W. Z. Wu, Chemical Engineering Science, vol. 3140, no. 65, (2010), Doi: http://dx.doi.org/10.1016/j.ces.2010.02.005.

[26] G. Raju, P. Shiva Reddy, J. Ashok, B. Mahipal Reddy and A. Venugopal, J. Natural Gas Chemistry, vol. 293, no. 17, (2008), Doi: http://dx.doi.org/10.1016/S1003-9953(08)60067-5.

[27] S. C. Xiang, W. Zhou, J. M. Gallegos, Y. Liu and B. L. Chen, J. Am. Chem. Soc., vol. 12415, no. 131, (2009), Doi: http://dx.doi.org/10.1021/ja904782h.

[28] A. R. Millward and O. M. Yaghi, J. Am. Chem. Soc., vol. 17998, no. 127, (2005), Doi: http://dx.doi.org/10.1021/ja0570032.

\section{Authors}

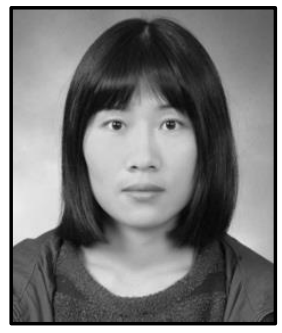

\section{Mei Mei Peng}

She finished her B.S from Department of Traditional Chinese Medicinal Material Resource Science, Anhui University of Traditional Chinese Medicine (2008). She completed her post graduate in the Department of Chemical Engineering, Hanseo University, South Korea (2012. 02). Now she is doing her research studies in the Department of Chemical Engineering, Hanseo University. Until now she contributed as first and co-authored in more than 20 research papers in various national and international Journals and presented more than 10 papers in conferences.

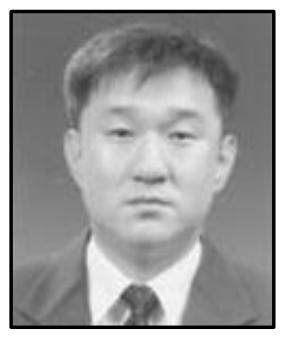

\section{Hyun Tae Jang}

He obtained his $\mathrm{PhD}$ in $\mathbf{1 9 9 6}$ from the department of Chemical engineering, Korea University. He joined as a faculty in the Department of Chemical Engineering, Hanseo University, South Korea (1997), during his research journey he has carried various research project funded by various National funding bodies. By his hard work and research initiatives now he becomes Prof in the same department and concurrently he carried as a head in TIC (Technology Innovation centre) of Hanseo University. He has appointed as reviewer for various national research funding agencies. For his credit he has published more than 70 research papers in various reputed journals, presented more than 100 research articles in various conferences and more than 10 patents. His research interest include designing of sorbents for $\mathrm{CO}_{2}$ sequestration and storage, removal of volatile organics form air and catalysis. 


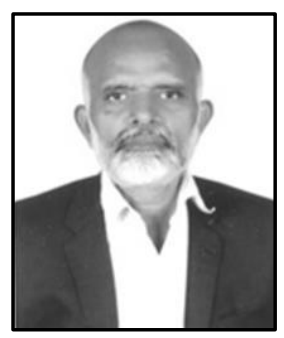

\section{Muthiahpillai Palanichamy}

He joined as a Demonstrator in the Department of Chemistry, Anna University, India in the year of 1978 and subsequently registered Ph.D. and awarded doctorate degree in 1988. For his credit, he has published more than 150 papers in reputed journals and has contributed more than 120 papers in National and International Conferences. He has visited South Korea as a Brain-pool scientist from 2007 to 2009. At present, he is working as a Brain-pool scientist in Prof. Hyun Tae Jang laboratory from 2012 onwards. 
International Journal of Control and Automation Vol.6, No.6 (2013) 